\title{
移植療法の長期予後
}

\author{
崎山幸雄
}

Jpn. J. Clin. Immun., 13 (5) : 496 498, 1990.

原発性免疫不全症候群に対して免疫機構の再建を目 的に行われる移植療法には胎児胸腺移植, 胎児肝移植, 骨髄移植がある。胎児胸腺移植は胸腺低 (無) 形成に よる DiGeorge 症候群に胸腺構造の構築を目的に, 胎 児肝移植と骨髄移植は重症複合免疫不全症 (SCID), Wiskott-Aldrich 症候群（WAS）などの重篤な T 細胞 機能不全を主病態とする複合型免疫不全症にリンパ幹 細胞の移植による免疫機構の再建を目的として行われ ている。本邦に打ける原発性免疫不全症候群は厚生省 免疫不全症候群調査研究班の疫学調査によると, これ までにおよそ 800 症例が登録されており，それらの中 でこれらの移植療法の適応となる疾患群は 160 例近く を占めている．本報告では限られた症例ではあるが, これまてに本邦で得られているリンパ幹細胞移植療法 の長期生存症例について, その概略を紹介し，とくに HLA-haploidentical donorによる骨髄移植例の長期 予後について考えてみたい.

\section{1. 本邦における移植療法による長期生存症例}

13 例の骨䯣移植と 2 例の胎児肝細胞移植による 15 症 例の長期生存例が集計された。疾患別ではSCID：14 例, WAS：1 例で, 骨䯣移植症例では 6 例が HLAidentical の兄もしくは姉を donor, 1 例が HLA-identical の他人を donor, 6 例が HLA-haploidentical の 父母をdonor として行われていた。表 1 に示した症例 1 11（男性：10, 女性：1）は全例が SCID で, 症例 1 6 は HLA-identical $の$ 兄：5症例, 姉： 1 症例よ り生後 $5 \sim 13$ 力月時に未分画の骨髄移植を前処置なく 受け，5例がサイクロスポリン A，1例がメソトレキセ 一トの GVHD 予防内服を受けていたが，GVHDは 1 例に glade IIで治療を要したのみで, 全例に生着を認

北海道大学小児科
めた. 症例 7〜11（男性：5）は HLA-haploidentical の父母より生後 6〜12 力月時に T 細胞除去処理した骨 䯣移植を前処置なく受け，2例がサイクロスポリンA, 1 例がメソトレキセートの予防内服を受けていたが，3 例に glade I の GVHD，1 例に chroic GVHD を認め たのみであった。症例 1〜6では移植後 1 力月以内に全 例が T, B リンパ球機能の改善の兆しを認め, 1〜6力 月でほほ正常の $\mathrm{T}$ 細胞, $\mathrm{B}$ 細胞機能が構築されて, 移 植 10〜112 力月を経た現在, 自宅で正常の日常生活を 送っている.一方, HLA-haploidentical donorによる 骨髄移植の症例 7 11 では症例 7 は移植 22 力月後の現 在, chronic GVHD で入院加療中である.

症例 8〜11 は移植 1〜3 カ月で $\mathrm{T}$ 細胞機能構築の兆 しを認め, 症例 8, 10 は移植 30,48 力月を経た現在 B 細胞機能の構築は部分的で静注用兔疫グロブリン （IVIG）による置換療法を持続し自宅で日常生活を送つ ている. 症例 9 は移植 5 力月で $\mathrm{T}$ 細胞機能が再建され, 9 カ月後には donor タイプの B 細胞が優位となり B細 胞機能も正常化, 症例 11 では $\mathrm{T}$ 細胞機能は 2 年後に 正常化し, B 細胞機能は 5 年後に正常化して, 両症例 ともIVIG の置換療法なしに正常の日常生活を送ってい る.

HLA-identical donor の他人ょり BMT を受けた症 例 12 では移植 1 力月後に $\mathrm{T}, \mathrm{B}$ 細胞の機能改善の兆し を認め, T 細胞は移植 4 力月後にはほほ正常化するも $\mathrm{B}$ 細胞は recipient タイプが主体で移植 88 力月の現在 も IVIG 置換療法下に自宅での生活を送っている. 症例 13，14 はいずれも胎生 10 週，9週の胎児肝移植を受け た複合免疫不全症で B 細胞機能は移植後 115 力月, 60 カ月の現在も構築されず IVIG 置換療法を受けている. 症例 15 は HLA-haploidentical donor の父より骨餚 移植を受けたWAS 症例で移植 5 力月後には正常の免 疫能を再建し移植 37 カ月後の現在, 自宅で正常の日常 
表 1 Longterm survivals of HLA-identical and haploidentical bone marrow transplantation in SCID

\begin{tabular}{|c|c|c|c|c|c|}
\hline Patient & $\begin{array}{l}\text { Lymphoid } \\
\text { function }\end{array}$ & $\begin{array}{l}\text { No. of days } \\
\text { to first rise } \\
\text { in function }\end{array}$ & $\begin{array}{l}\text { No. of days } \\
\text { to normal } \\
\text { function }\end{array}$ & $\begin{array}{l}\text { Months } \\
\text { post } \\
\text { transpl. }\end{array}$ & Status \\
\hline 1. T.M. & Full & $<30$ & 120 & 10 & at home \\
\hline 2. S.M. & Full & $<30$ & 180 & 12 & at home \\
\hline 3. Y.O. & Full & $<30$ & 250 & 18 & at home \\
\hline 4. R.T. & Full & $<30$ & 60 & 64 & at home \\
\hline 5. K. I . & Full & $<30$ & 150 & 63 & at home \\
\hline 6. T.S. & Full & $<30$ & 240 & 112 & at home \\
\hline \multirow[t]{2}{*}{ 7. Y.F. } & Part. $T$ & & - & 22 & in hospital \\
\hline & Part. B & 90 & - & & \\
\hline \multirow[t]{2}{*}{ 8. T.K. } & Part. T & $<30$ & 150 & 30 & at home \\
\hline & Part. B & 40 & - & & IVIG \\
\hline 9. K.D. & $\begin{array}{c}\text { Full } \\
\text { (Donor B) }\end{array}$ & $<30$ & $\begin{array}{c}150 \\
(9 \mathrm{mo} .)\end{array}$ & 37 & $\begin{array}{l}\text { at home } \\
\text { MMR take }\end{array}$ \\
\hline \multirow[t]{2}{*}{ 10. S.T. } & Part. $T$ & 90 & & 48 & at home \\
\hline & Part. B & 170 & & & IVIG \\
\hline \multirow[t]{2}{*}{ 11. A.Y. } & Part. T & 105 & $24 \mathrm{mo}$. & 93 & at home \\
\hline & Part. B & 270 & $60 \mathrm{mo}$ & & \\
\hline
\end{tabular}

表 2 Longterm survivals of bone marrow and fetal organ transplantation in primary immunodeficiency diseases

\begin{tabular}{rlcccc}
\hline Patient & $\begin{array}{l}\text { Lymphoid } \\
\text { function }\end{array}$ & $\begin{array}{l}\text { No. of days } \\
\text { to first rise } \\
\text { in function }\end{array}$ & $\begin{array}{l}\text { No. of days } \\
\text { to normal } \\
\text { function }\end{array}$ & $\begin{array}{l}\text { Months } \\
\text { post } \\
\text { transpl. }\end{array}$ & Status \\
\hline 12. A.Y. & $\begin{array}{l}\text { Full T } \\
\text { Part. B(R) }\end{array}$ & $\begin{array}{c}<30 \\
<30\end{array}$ & 120 & 88 & $\begin{array}{c}\text { at home } \\
\text { IVIG } \\
\text { 13. Y.Y. }\end{array}$ \\
$\begin{array}{l}\text { Part. T } \\
\text { Part. B }\end{array}$ & 100 & & 115 & $\begin{array}{c}\text { in hospital } \\
\text { IVIG }\end{array}$ \\
14. S.H. & Part. T & $<30$ & 360 & 60 & $\begin{array}{c}\text { at home } \\
\text { IVIG }\end{array}$ \\
15. N.M. & Full & $<30$ & 150 & 37 & at home \\
\hline
\end{tabular}

生活を送っている(表 2 ).

\section{2. 移植療法の長期予後}

本邦における移植療法の状況に関してはこれまでに 1983 年に松本らが 1981 年に行われた症例 6 とそれまで の胎児肝移植の 2 症例（症例 13 , 他の 1 症例はその後 死亡）を中心に HLA-identical donor からの骨䯣移植 により SCIDの免疫機構を構築しえたことを，また 1986 年には矢田がそれまでの本邦での 16 例の原発性免疫不 全症における骨髄移植症例（7 例の生存例を含む）に
ついて報告し，HLA-haploidentical donorでも移植骨 髄より T 細胞を除去することにより移植が可能である ことをアンケート調查により集計報告している，兔疫 機構が再建された生存症例は 6 例で, 4 例が HLAidentical donor (unrelated HLA-identical donor 例 の症例 12 を含む) よりの移植例, 2 例が HLA-haploidentical donor よりの移植例で WAS 例 (症例 15) と症例 11 である. その後, 1989 年までの 4 年間に新た にHLA - identical donorの 3 例, HLA - haploidentical donor $の 4$ 例が長期生存例として治療され 
表 3 Study of longterm survivals of HLA-identical and haploidentical bone marrow transplantation in primary immunodeficiency diseases

\begin{tabular}{cccl}
\hline BMT & $\begin{array}{l}\text { NO. of } \\
\text { case }\end{array}$ & $\begin{array}{l}\text { Months post } \\
\text { transplantation }\end{array}$ & \multicolumn{1}{c}{ Status } \\
\hline HLA-identical & $7(1)$ & $10 \sim 112$ & 6 pts. : well at home \\
& & 88 & One pt. : IVIG, at home \\
Haploidentical & 6 & 22 & One pt. : in hospital \\
& & 30,48 & 2 pts. : IVIG, at home \\
& & $37 \sim 93$ & 3 pts. : well at home \\
\hline
\end{tabular}

ている.これまでの長期生存 15 症例の中で骨䯣移植に より長期生存を得た 13 例を移植骨䯣が HLA-identical donor $の$ 症例と HLA-haploidentical donor $の$ 症例と に分けて表 3 にその要約を示した. HLA - haploidentical donorによる骨髄移植は HLA-identical donor の兄姉よりの移植に比してその免疫機構の構築に より時期を要し，かつ B 細胞機能の構築は部分的であ る傾向を認めた. R.H. Buckley らは 1989 年，10月ま でに 30 例の SCID に大豆アグルチニンによる凝集と羊 赤血球によるロゼット形成法で Haploidentical donor の骨髄細胞より T 細胞を除去した後に移植することに より前処置，GVHDの予防内服のいずれも行うことな く22 例 $(73 \%)$ の長期生存例を得たことを報告してい る. T細胞は $100 \%$ donor 由来で $1 \sim 10$ カ月でその $80 \%$ が正常機能を獲得し，B 細胞は 3 例のみが donor 由来で, 特異抗体の産生は 2 2.5 年でその $50 \%$ に認 められている。これら本邦例を含めた長期生存症例の 報告は SCID の少なくとも半数の患者では HLA-ha. ploidentical donor 由来のリンパ幹細胞が患者の既存す る胸腺構造の影響の下に正常の $\mathrm{T}$ 細胞に分化, 成熟し, recipient 由来の B 細胞と抗体産生を起こしうること, また B 細胞の特異抗体産生能の獲得は HLA-identical donor の移植に比較して緩徐であることを示唆している.
本邦の長期生存例を含めHLA - haploidentical donor による骨䯣移植は HLA-identical donor のそれ とほほ同数の長期生存症例を得ている。これは HLAhaploidentical donorによる骨髄移植がT細胞を除去 した分画骨髄細胞を用いることにより重篤な GVHDを 葶起することなく生着することを明らかにし，多くの SCID 患児では HLA-identical donor の存在がきわめ て限られ，donorを得られない状況下にあることもあっ て骨髄移植が行われはじめた初期に比較すると HLAhaploidentical donor よりの骨髄移植は免疫機構の構 築療法として今後も有用な治療法であろう。しかし現 状では B 細胞機能の構築は HLA-identical donorに比 較すると明らかに低く，遅れており，IVIG の置換療法 を含めた十分な経過観察が年余にわたって必要とされ るとともに B 細胞機能が構築されない患児の胸腺構造 を含めた欠陥を明らかにすることが問題として残され ている.

本報告にあたり，以下の施設から症例の御報告を頂 いた。ここに深謝する。

東北大学小児科，国立小児病院感染科，神奈川県立 小児医療センタ一感染免疫科, 東海大学小児科, 名古 屋大学小児科, 久留米大学小児科, 東京大学小児科, 太田総合病院小児科, 北海道大学小児科. 